\title{
Optimization of cultivation conditions for the production of phytate-degrading enzymes by Enterobacter sakazakii ASUIA279 isolated from Malaysian maize root
}

\author{
Anis Shobirin Meor Hussin ${ }^{1}$, Abd-EIAziem Farouk ${ }^{2}$ and Ralf Greiner ${ }^{3 *}$ \\ ${ }^{1}$ Faculty of Science and Technology, University Putra Malaysia, 43400, UPM, Serdang, Selangor, ${ }^{2}$ Department of \\ Biotechnology, Faculty of Science, Taif University, P. Box 888, AlHawiya, Kingdom of Saudi Arabia, ${ }^{3}$ Max Rubner- \\ Institut, Federal Research Institute of Nutrition and Food, Department of Food Technology and Bioprocess \\ Engineering, Haid-und-Neu-Strasse 9, 76131 Karlsruhe, Germany.
}

\begin{abstract}
The production of extracellular phytase by Enterobacter sakazakii ASUIA279 was optimized using response surface methodology with full-factorial faced centred central composite design. Two sets of experiments were carried out to optimize the five most profound factors of the cultivation conditions in order to maximize phytase production. Incubation temperature, initial $\mathrm{pH}$ of the media and percentage of rice bran supplemented into the media were optimized in Erlenmeyer flasks while agitation and aeration effect were controlled in a bioreactor. This design reduced the number of actual experiment performed to optimize phytase production and allowed the study of possible interactions among the factors. In the first set of experiments linear and quadratic effect of initial $\mathrm{pH}$ was determined to be the most significant factor affecting phytase production. In the bioreactor both linear effects of agitation and aeration, were identified to be highly significant (> $99 \%$ ) in respect to phytase yields. Optimal phytase production was observed at a incubation temperature of $39.7^{\circ} \mathrm{C}$, an initial pH of 7.1, supplementation with $13.6 \%$ rice bran, 320 rpm of agitation and $0 \mathrm{vvm}$ of aeration.
\end{abstract}

Key-words: Bacterial phytase, statistical optimization, cultivation conditions

\section{INTRODUCTION}

Most cereals and legumes are rich in protein and fat but the presence of phytate discourages their use in food. Approximately $70 \%$ of total phosphorus in cereal grains and legume seeds exists as phytate. The phytate is poorly utilized by monogastric animals and acts as an anti-nutrient due to its chelating of various metals and binding of protein. This diminishes the bioavailability of proteins and nutritionally important minerals. In animal diets, the supply of phosphorus, an essential mineral salt for animal growth and development, comes from either the feedstuffs or from inorganic phosphate added to the diets (Poulsen, 2000). These nutritional impediments result in the release of undigested phytate phosphorus in the feces. Phosphorus in the environment accelerates eutrophication of fresh waters and is the main problem in surface water quality, resulting in restricted water use for fisheries, recreation, industry and drinking (Krishna and Nokes, 2001).
Phytate degrading enzymes or phytases convert phytate to partially phosphorylated myo-inositol and phosphate, making phosphorus available for absorption (Irving and Cosgrove, 1972). Supplementation of microbial phytase to animal diets alters the phytate complexes and also increases the bioavailability of proteins and essential minerals, providing growth performance equivalent or better than those with phosphate supplementation, and also reduces the amount of phosphorus in animal manure (Wodzinski and Ullah, 1996). To obtain a good source of phytase, a variety of microorganism has been screened for the enzymes such as Bacillus sp. (Powar and Joganathan, 1982; Choi et al., 1999), Klebsiella terrigena (Greiner et al., 1997), Pseudomonas sp. (Irving and Cosgrove, 1971), Escherichia coli (Greiner et al., 1993), Myceliophthora thermophila (Mitchell et al., 1997), Aspergillus terreus (Yamada et al., 1968), Aspergillus niger (Nagashima et al., 1999), Aspergillus fumigatus (Pasamontes et al., 1997) and ruminal bacteria

*Author for correspondence: ralforeiner@vahoo.de

J. Biotec. Biodivers. v. 3, N.2: pp. 1-10, May. 2012 
(Yanke et al., 1998). Partial optimization of the cultivation conditions for the productivity is becoming one of the major goals in biotechnology today. The productivity of any cultivation is affected by process parameters and media composition (Park and Reardon, 1996). Preliminary experiments in our laboratory indicated that rice bran composition and physical parameter of cultivation conditions play a significant role in phytase production. Therefore an investigation was performed to statistically optimize the cultivation conditions for the production of the highly potential extracellular phytase from Enterobacter sakazakii ASUIA279. Response surface methodology (RSM) is now being routinely used for optimization studies in several biotechnological and industrial processes (Beg et al., 2002; De Cornick et al., 2000; Puri et al., 2002). RSM is used to explain the interaction among the possible influencing parameters with limited numbers of parameters.

In this paper, we determine the optimum composition of rice bran supplement in the media, initial $\mathrm{pH}$ of the media, incubation temperature, agitation and aeration during cultivation for phytase production by using full factorial Face Centred Central Composite Design in RSM.

\section{MATERIALS AND METHODS}

\section{Microorganism and culture conditions}

Enterobacter sakazakii ASUIA279 was isolated from the endophyte of Malaysian Maize root and identified using biochemical and phylogenetic analysis (Anis Shobirin, 2008). The strain was maintained on agar slopes at $4^{\circ} \mathrm{C}$. LB broth (Merck) with initial $\mathrm{pH}$ of 7.0 in universal bottle used as the standard inoculum medium and kept in incubating shaker at $37^{\circ} \mathrm{C}$ and $200 \mathrm{rpm}$ for $18 \mathrm{~h}$.

\section{Chemicals}

Phytic acid, dodecasodium salt, was purchased from Sigma Chemical Co. (St. Louis, Mo.). All other chemicals and media were of analytical grade.

\section{Standard Phytase Assay}

Phytate-degrading activity was determined at $50^{\circ} \mathrm{C}$ in $390 \mu \mathrm{l} 100 \mathrm{mM}$ sodium acetate buffer, $\mathrm{pH} 5.0$ containing $1.03 \mathrm{mM}$ sodium phytate. The enzymatic reaction was started by adding $10 \mu \mathrm{l}$ of enzyme solution to the assay mixture. After incubating for $30 \mathrm{~min}$ at $50^{\circ} \mathrm{C}$, the liberated phosphate was measured according to ammonium molybdate method (Heinonen and Lahti, 1981) with some modifications. Added to the assay mixture was $1.5 \mathrm{ml}$ of a freshly prepared solution of acetone: $5 \mathrm{~N} \mathrm{H}_{2} \mathrm{SO}_{4}$ : $10 \mathrm{mM}$ ammonium molybdate $(2: 1: 1 \mathrm{v} / \mathrm{v})$ and $100 \mu \mathrm{l}$ citric acid. Any cloudiness was removed by centrifugation prior to the measurement of absorbance at $355 \mathrm{~nm}$. To calculate the enzyme activity, a calibration curve was produced over the range of 5-600 mmol phosphate ( $\left.\varepsilon=8.7 \mathrm{~cm}^{2} / \mathrm{nmol}\right)$. Activity (units) was expressed as $1 \mu \mathrm{mol}$ phosphate liberated per minute. Blanks were run by addition the ammonium molybdate solution prior to adding the enzyme to the assay mixture.

\section{Experimental design}

After preliminary optimizing the values of various nutritional and physical factors in individually, the five most important factors in respect to phytase production by Enterobacter sakazakii ASUIA279, namely rice bran concentration $\left(\mathrm{X}_{1}\right)$, incubation temperature $\left(\mathrm{X}_{2}\right)$, initial $\mathrm{pH}\left(\mathrm{X}_{3}\right)$, agitation speed $\left(\mathrm{X}_{4}\right)$ and aeration volume $\left(\mathrm{X}_{5}\right)$ were identified under batch fermentation conditions. Taking the above factors and constraint of time into consideration, a response surface methodology using a two-step experimental design was adopted for improving total phytate-degrading enzyme secretion from Enterobacter sakazakii ASUIA279. The experiments involved the phytate-degrading enzyme production for 20 run in Erlenmeyer flask (see table 2) and then scaling up in a bioreactor for 13 run (see table 3 ).

In step-one, $10 \mathrm{ml}$ of inoculums $(10 \% \mathrm{v} / \mathrm{v})$ were transferred into $250 \mathrm{ml}$ Erlenmeyer flasks containing $100 \mathrm{ml}$ production medium for optimization of the rice bran concentration, the initial $\mathrm{pH}$ of media and the incubating temperature. The flasks were then placed in an orbital shaker at $200 \mathrm{rpm}$. The experiments were done in triplicate. While in step-two, $2 \mathrm{~L}$ bioreactor (Biostat ${ }^{\circledR}$ B-DCU- B. Braun Biotech International, Sartorius Group) containing 1 L production medium was used for optimization of the agitation and the aeration. The production medium, the initial $\mathrm{pH}$ of the media and the incubation temperature was the optimized conditions derived from step-one. The samples of each one were analyzed three times. Samples of $1.5 \mathrm{ml}$ were withdrawn from both steps after 5 days of incubation.

Full-factorial Central Composite Experimental Design with centred face was used to optimize the 
cultivation conditions for phytate-degrading enzyme production by Enterobacter sakazakii ASUIA279. The experiments were designed by using the Minitab 14 Statistical Software. A $2^{3}-$ factorial experimental design with four axial points (with $\alpha=1$ and six replicates at the centre point $\left(\mathrm{n}_{0}=6\right)$ leading to a total number of twenty experiments was employed for the optimization of rice bran composition $\left(\mathrm{X}_{1}\right)$, initial $\mathrm{pH}\left(\mathrm{X}_{2}\right)$ of media and incubation temperature $\left(\mathrm{X}_{3}\right)$ in Erlenmeyer flasks and a $2^{2}-$ factorial experimental design leading to thirteen trials for the optimization of agitation $\left(\mathrm{X}_{4}\right)$ and aeration $\left(\mathrm{X}_{5}\right)$ in a $2 \mathrm{~L}$ bioreactor.
The design matrix and levels of the independent variables chosen for the study in encoded in a form shown in table 1 . The range of the variable chosen is based on other studies (Vohra and Satyanarayana, 2003). The average of the maximum phytate-degrading enzyme activity of the duplicate values obtained was taken as dependent variable or response Yi (U). Regression analysis and isoresponse contour plots were performed on the data obtained using MINITAB 14. Microsoft Office Excel 2003 is used to calculate the predicted responses.

Table 1. Experimental range and levels of the independent variables for phytate-degrading enzyme production.

\begin{tabular}{lcccc}
\hline Variables & Symbol coded & \multicolumn{3}{c}{ Range and level } \\
\cline { 3 - 5 } & & -1 & 0 & +1 \\
\hline Temperature $\left({ }^{\circ} \mathrm{C}\right)$ & $\mathrm{X}_{1}$ & 29 & 37 & 45 \\
Initial $\mathrm{pH}$ & $\mathrm{X}_{2}$ & 5 & 7 & 9 \\
Rice bran \% $(\mathrm{w} / \mathrm{v})$ & $\mathrm{X}_{3}$ & 5 & 10 & 15 \\
Agitation $(\mathrm{rpm})$ & $\mathrm{X}_{4}$ & 200 & 300 & 400 \\
Aeration $(\mathrm{vvm})$ & $\mathrm{X}_{5}$ & 0 & 1 & 2 \\
\hline
\end{tabular}

The final validation of the statistical regression model for prediction of phytate-degrading enzyme production from Enterobacter sakazakii ASUIA279 was carried out in both steps. Samples were withdrawn for phytase assay after 5 days of cultivation.

\section{RESULTS}

From the preliminary study, the factors that have the major influence for the production of phytatedegrading enzymes by Enterobacter sakazakii ASUIA279 were the composition of rice bran, incubation temperature, initial $\mathrm{pH}$, agitation and aeration. Due to apparatus and time constraints, the experiments were split into two sets where the first three factors were optimized in Erlenmeyer flask. With the optimized cultivation conditions derived from the first set od experiments, agitation and aeration were optimized in a $2 \mathrm{~L}$ bioreactor The response was taken at the maximum phytatedegrading enzyme activity, which was observed after 5 days of fermentation. Table 2 and 3 summarize the phytate-degrading enzyme activity (response) of the experiments for both steps. The coefficients of the regression equation were calculated using MINITAB 14 and the following regression equations were obtained.

Step-one;

$Y=-44.4+1.15 X_{1}+6.96 X_{2}-0.165 X_{3}-0.0212$ $X_{1}^{2}-0.759 X_{2}^{2}-0.0439 X_{3}^{2}+0.0991 X_{1} X_{2}+$ $0.0299 X_{1} X_{3}+0.226 X_{2} X_{3}-0.00595 X_{1} X_{2} X_{3}(1)$

$\mathrm{R}^{2}=97.4 \%$

Step-two;

$Y=-7.03+0.102 X_{4^{-}} 3.93 X_{5^{-}} 0.000156 X_{4}^{2}+$ $0.586 X_{5}^{2}-0.00172 X_{4} X_{5}$.(2)

$\mathrm{R}^{2}=98.3 \%$

Where $Y=$ the response or phytate-degrading enzyme activity

$X_{1}=$ temperature $\left({ }^{\circ} \mathrm{C}\right)$

$X_{2}=\mathrm{pH}$

$X_{3}=$ rice bran $(\% \mathrm{w} / \mathrm{v})$

$X_{4}=\operatorname{agitation}(\mathrm{rpm})$

$X_{5}=$ aeration $(\mathrm{vvm})$ 
Table 2. Experimental design of three independent variables in step-one showing experimental responses

\begin{tabular}{ccccc}
\hline $\begin{array}{c}\text { Experiment } \\
\text { run no. }\end{array}$ & $\begin{array}{c}\text { Temperature } \\
\left({ }^{\circ} \mathrm{C}\right)\end{array}$ & $\mathrm{pH}$ & $\%$ Rice Bran & $\begin{array}{c}\text { Experimental } \\
\text { Phytase Activity }(\mathrm{U} / \mathrm{ml})\end{array}$ \\
\hline 1 & 37 & 7 & 10 & 12.009 \\
2 & 45 & 5 & 5 & 6.360 \\
3 & 45 & 5 & 15 & 7.227 \\
4 & 37 & 7 & 10 & 12.408 \\
5 & 29 & 5 & 5 & 5.030 \\
6 & 37 & 7 & 10 & 12.058 \\
7 & 29 & 7 & 10 & 8.708 \\
8 & 37 & 7 & 5 & 9.393 \\
9 & 37 & 7 & 15 & 10.506 \\
10 & 45 & 7 & 10 & 10.673 \\
11 & 45 & 9 & 5 & 8.696 \\
12 & 37 & 9 & 10 & 8.118 \\
13 & 29 & 5 & 15 & 5.883 \\
14 & 37 & 7 & 10 & 11.209 \\
15 & 37 & 5 & 10 & 7.905 \\
16 & 37 & 7 & 10 & 11.839 \\
17 & 37 & 7 & 10 & 12.197 \\
18 & 29 & 9 & 5 & 2.931 \\
19 & 29 & 9 & 15 & 5.903 \\
20 & 45 & 9 & 15 & 7.871 \\
\hline
\end{tabular}

Table 3. Experimental design of two independent variables in step-two showing experimental responses.

\begin{tabular}{cccc}
\hline $\begin{array}{c}\text { Experiment } \\
\text { run no. }\end{array}$ & $\begin{array}{c}\text { Agitation } \\
(\mathrm{rpm})\end{array}$ & Aeration $(\mathrm{vvm})$ & $\begin{array}{c}\text { Experimental } \\
\text { Phytase Activity }(\mathrm{U} / \mathrm{ml})\end{array}$ \\
\hline 1 & 300 & 0 & 10.237 \\
2 & 300 & 1 & 5.583 \\
3 & 400 & 2 & 2.108 \\
4 & 300 & 1 & 5.891 \\
5 & 300 & 1 & 5.460 \\
6 & 200 & 0 & 6.835 \\
7 & 200 & 2 & 1.229 \\
8 & 400 & 0 & 8.402 \\
9 & 400 & 1 & 5.011 \\
10 & 300 & 1 & 5.664 \\
11 & 300 & 2 & 2.515 \\
12 & 200 & 1 & 3.448 \\
13 & 300 & 1 & 5.545 \\
\hline
\end{tabular}

The significance of each coefficient was determined by $\mathrm{T}$ values and $\mathrm{P}$ values which are listed in table 4 and 5. From t-table, alpha value of 0.05 and degree of freedom of 19 , the critical value of $t$ is 1.73 (step-one) while for degree of freedom of 12, the critical value of $t$ is 1.78 (steptwo). Therefore, factors with $\mathrm{t}$ values greater than $\mathrm{t}$ critical are significant to the model. Based on the t-test results, it is observed from table 6 that the coefficient for temperature $\left(\mathrm{X}_{1}\right)$ and initial $\mathrm{pH}\left(\mathrm{X}_{2}\right)$ are the most significant factors for step-one. Furthermore, the quadratic interactions $\mathrm{X}_{1}{ }^{2}, \mathrm{X}_{2}^{2}$, $\mathrm{X}_{3}{ }^{2}$ and the factor of interactions $\mathrm{X}_{1} \mathrm{X}_{2}$ (temp, $\mathrm{pH}$ ), $\mathrm{X}_{2} \mathrm{X}_{3}\left(\mathrm{pH}, \%\right.$ rice bran), $\mathrm{X}_{1} \mathrm{X}_{2} \mathrm{X}_{3}$ (temp, $\mathrm{pH}, \%$ rice bran) were also found to be very significant. 
Table 4. The least-squares fit and parameter estimates (significance of regression coefficient) for stepone.

\begin{tabular}{lcccc}
\hline \multicolumn{1}{c}{ Predictor } & Coefficient & SE Coefficient & $\mathrm{T}$ & $\mathrm{P}$ \\
\hline Constant & -44.44 & 11.140 & -3.99 & 0.003 \\
$\mathrm{X}_{1}$ & 1.148 & 0.505 & $2.27^{*}$ & 0.049 \\
$\mathrm{X}_{2}$ & 6.960 & 1.815 & $3.84^{*}$ & 0.004 \\
$\mathrm{X}_{3}$ & -0.165 & 0.843 & -0.20 & 0.849 \\
$\mathrm{X}_{1}{ }^{2}$ & -0.021 & 0.006 & $-3.49^{*}$ & 0.007 \\
$\mathrm{X}_{2}{ }^{2}$ & -0.759 & 0.097 & $-7.82^{*}$ & 0.000 \\
$\mathrm{X}_{3} \mathrm{X}_{1} \mathrm{X}_{2}$ & -0.044 & 0.016 & $-2.83^{*}$ & 0.020 \\
$\mathrm{X}_{1} \mathrm{X}_{3}$ & 0.099 & 0.032 & $3.11^{*}$ & 0.012 \\
$\mathrm{X}_{2} \mathrm{X}_{3}$ & 0.030 & 0.021 & 1.44 & 0.183 \\
$\mathrm{X}_{1} \mathrm{X}_{2} \mathrm{X}_{3}$ & 0.226 & 0.108 & $2.10^{*}$ & 0.066 \\
\hline
\end{tabular}

* indicates significance to the model.

Table 5 shows that the coefficient for both agitation speed $\left(\mathrm{X}_{4}\right)$ and aeration $\left(\mathrm{X}_{5}\right)$ as well the quadratic interaction $\mathrm{X}_{4}^{2}$ and $\mathrm{X}_{5}^{2}$ are significant factors for step-two. These significant factors are very important as they indicates the limiting factors in which the smallest variations in their values can alter the phytate-degrading enzyme production.

Table 5. The least-squares fit and parameter estimates (significance of regression coefficient) for steptwo.

\begin{tabular}{lcccc}
\hline \multicolumn{1}{c}{ Predictor } & Coefficient & SE Coefficient & $\mathrm{T}$ & $\mathrm{P}$ \\
\hline Constant & -7.030 & 2.302 & -3.05 & 0.018 \\
$\mathrm{X}_{4}$ & 0.102 & 0.016 & $6.53^{*}$ & 0.000 \\
$\mathrm{X}_{5}$ & -3.927 & 0.837 & $-4.69^{*}$ & 0.002 \\
$\mathrm{X}_{4}{ }^{2}$ & -0.0001 & 0.000 & $-6.09^{*}$ & 0.000 \\
$\mathrm{X}_{5}{ }^{2}$ & 0.586 & 0.256 & $2.29^{*}$ & 0.056 \\
$\mathrm{X}_{4} \mathrm{X}_{5}$ & -0.002 & 0.002 & -0.81 & 0.446 \\
\hline
\end{tabular}

* indicates significance to the model.

The coefficients of the regression equation were re-analysed and calculated using MINITAB 14 and the following regression equations were obtained.

Step-one,

$\mathrm{Y}=-61.5+1.84 X_{1}+9.35 X_{2}-0.0266 X_{1}^{2}-0.845$

$X_{2}^{2}-0.00718 X_{3}^{2}+0.0596 X_{1} X_{2}+0.107 X_{2} X_{3}-$ $0.00201 X_{1} X_{2} X_{3} \ldots$ (3)

$\mathrm{R}^{2}=94.7 \%$

Step-two,

$$
\begin{aligned}
& Y=-6.51+0.100 X_{4}-4.44 X_{5}-0.000156 \\
& X_{4}^{2}+0.586 X_{5}^{2}(4) \\
& \mathrm{R}^{2}=98.1 \%
\end{aligned}
$$

Where $Y=$ the response or phytate-degrading enzyme activity

$X_{1}=$ temperature $\left({ }^{\circ} \mathrm{C}\right)$

$X_{2}=\mathrm{pH}$

$X_{3}=$ rice bran $(\% \mathrm{w} / \mathrm{v})$
$X_{4}=\operatorname{agitation}(\mathrm{rpm})$

$X_{5}=$ aeration $(\mathrm{vvm})$

The regression equation and determination coefficient $R^{2}$ were evaluated to test the fit of the model. The model presented a high determination coefficient of $90.8 \%$ for step-one and $98.1 \%$ in step-two of the variability in the response.

Table 6 and 7 summarize the phytate-degrading enzyme activity (response) of the experiments for both steps with the predicted response. The predicted responses were calculated using the reanalysed regression equation. The high value of $R^{2}$ indicating the high significance of the model. It revealed a good agreement between the experimental and predicted values of the responses. From the predicted responses, the optimum operating conditions for the enzyme production were at temperature of $37^{\circ} \mathrm{C}$, initial $\mathrm{pH}$ of 7 , rice bran of $15 \%, 300 \mathrm{rpm}$ of agitation speed and $0 \mathrm{vvm}$ of aeration. 
Table 6. Experimental design of three independent variables in step-one showing experimental and predicted responses.

\begin{tabular}{cccccc}
\hline $\begin{array}{c}\text { Experiment } \\
\text { run no. }\end{array}$ & Temperature $\left({ }^{\circ} \mathrm{C}\right)$ & $\mathrm{pH}$ & \% Rice Bran & Phytase Activity $(\mathrm{U} / \mathrm{ml})$ \\
\hline 1 & 37 & 7 & 10 & 12.009 & 11.212 \\
2 & 45 & 5 & 5 & 6.360 & 6.704 \\
3 & 45 & 5 & 15 & 7.227 & 6.096 \\
4 & 37 & 7 & 10 & 12.408 & 11.212 \\
5 & 29 & 5 & 5 & 5.030 & 4.795 \\
6 & 37 & 7 & 10 & 12.058 & 11.212 \\
7 & 29 & 7 & 10 & 8.708 & 8.325 \\
8 & 37 & 7 & 5 & 9.393 & 10.609 \\
9 & 37 & 7 & 15 & 10.506 & 11.457 \\
10 & 45 & 7 & 10 & 10.673 & 10.695 \\
11 & 45 & 9 & 5 & 8.696 & 7.843 \\
12 & 37 & 9 & 10 & 8.118 & 7.935 \\
13 & 29 & 5 & 15 & 5.883 & 5.794 \\
14 & 37 & 7 & 10 & 11.209 & 11.212 \\
15 & 37 & 5 & 10 & 7.905 & 7.729 \\
16 & 37 & 7 & 10 & 11.839 & 11.212 \\
17 & 37 & 7 & 10 & 12.197 & 11.212 \\
18 & 29 & 9 & 5 & 2.931 & 2.762 \\
19 & 29 & 9 & 15 & 5.903 & 5.710 \\
20 & 45 & 9 & 15 & 7.871 & 7.897 \\
\hline
\end{tabular}

Table 7. Experimental design of two independent variables in step-two showing experimental and predicted responses.

\begin{tabular}{ccccc}
\hline $\begin{array}{c}\text { Experiment } \\
\text { run no. }\end{array}$ & $\begin{array}{c}\text { Agitation } \\
(\mathrm{rpm})\end{array}$ & Aeration $(\mathrm{vvm})$ & \multicolumn{2}{c}{ Phytase Activity $(\mathrm{U} / \mathrm{ml})$} \\
\cline { 4 - 5 } & 300 & 0 & 10.237 & Experimental \\
\hline 1 & 300 & 1 & 5.583 & Predicted \\
3 & 400 & 2 & 2.108 & 5.5506 \\
4 & 300 & 1 & 5.891 & 5.994 \\
5 & 300 & 1 & 5.460 & 5.596 \\
6 & 200 & 0 & 6.835 & 7.25 \\
7 & 200 & 2 & 1.229 & 0.714 \\
8 & 400 & 0 & 8.402 & 8.53 \\
9 & 400 & 1 & 5.011 & 4.676 \\
10 & 300 & 1 & 5.664 & 5.596 \\
11 & 300 & 2 & 2.515 & 2.914 \\
12 & 200 & 1 & 3.448 & 3.396 \\
13 & 300 & 1 & 5.545 & 5.596 \\
\hline
\end{tabular}

Figure 1 show the contour plot of the relative effects of two most significant factors when all the factors were kept at their central levels. The plots depicted interaction of incubation temperature and initial $\mathrm{pH}$ for phytase production in step-one. The contour plot clearly shows an ellipse where the optimum conditions can be easily determined. These indicate that there are major interactions among the independent variable corresponding to the response surface. Optimal production of phytate-degrading enzymes was observed at an incubation temperature of $39.7^{\circ} \mathrm{C}$, an initial $\mathrm{pH}$ of 
the medium of 7.1 and a rice bran supplementation of $13.6 \%$.

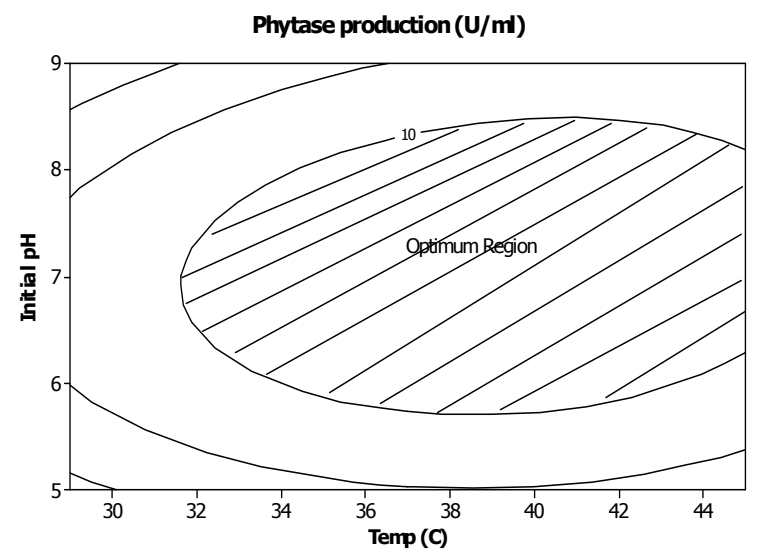

Figure 1 - Contour plot of phytate-degrading enzyme production from Enterobacter sakazakii ASUIA279 showing interaction between incubation temperature and initial $\mathrm{pH}$.

The validation of model with experimental data as well the predicted values from response surface model under the optimized cultivation conditions (included only the most significant coefficient) are presented in table 8. Phytate-degrading enzyme productions under the optimized cultivation conditions for the validation model for both steps were within the range of the predicted value from the response surface model. The optimization of these parameters using RSM has increased the production of phytate-degrading enzyme by Enterobacter sakazakii ASUIA279. There are no known reports on statistically optimization of temperature, initial $\mathrm{pH}$, rice bran concentration, agitation and aeration for production of phytase. Quan et al (2001) and Gautam et al (2002) had done an individual optimization (keeping other parameters as constant) on the effect of temperature and $\mathrm{pH}$ besides other parameters for phytase production. The effect of solid substrates (canola meal, corn meal, soy meal and wheat meal) has been optimized using Plackett- Burman Design by Bogar et al. (2003).

Table 8. Experimental (validation studies) and predicted results (from Response Surface Model) of phytate-degrading enzyme activity $(\mathrm{U} / \mathrm{ml})$ under optimized cultivation condition.

\begin{tabular}{cccc}
\hline \multicolumn{2}{c}{ Phytase Activity in Erlenmeyer Flask $(\mathrm{U} / \mathrm{ml})$} & \multicolumn{2}{c}{ Phytase Activity in Bioreactor $(\mathrm{U} / \mathrm{ml})$} \\
\hline Experimental & Predicted & Experimental & Predicted \\
\hline $11.14 \pm 0.12$ & 11.511 & $9.56 \pm 0.09$ & 9.516 \\
\hline
\end{tabular}

\section{DISCUSSION}

The conventional methods for multifactor experimental design are time-consuming and incapable of obtaining the true optimum, due especially to the interactions among the factors (Nagashima et al., 1999). In order to design a suitable bioprocess for optimized phytatedegrading enzyme production in Enterobacter sakazakii ASUIA279, the statistical design approach using response surface methodology with face centred central composite design (FCCCD) was used to study the interactive effects of various nutritional and physical factors on phytate-degrading enzyme production. According to Vohra and Satyanarayana (2003), the source and optimal concentration of carbon are important factors for the production of phytate-degrading enzyme and the most important physical parameters having profound influence on growth of organisms and production of metabolites from them are $\mathrm{pH}$, temperature, agitation, dissolved oxygen, and pressure.
Student's t-test was used to determine the significant coefficient of the experimental run. If the $\mathrm{T}$ value observed from the regression coefficient data was higher or equal to critical $t$ obtained from t-table, indicated that the coefficient was significant to the model. For step-one, at $\alpha=$ 0.05 , degree of freedom $=19$, and the critical value of $t$ is 1.73 , its shows that the most significant factor that affect the production of phytate-degrading enzymes were the incubation temperature and the initial $\mathrm{pH}$ of the medium. While for step-two, at $\alpha=0.05$, degree of freedom $=12$, and the critical value of $\mathrm{t}$ is 1.78 , both agitation speed and aeration were significant factors that affect production. The ANOVA of quadratic regression model demonstrates that the model is highly significant, as is evident from the Fishers F-test with very low probability value (P > $\mathrm{F}=0.0001$ ).

The larger the magnitude of the $\mathrm{T}$ value and the smaller the $\mathrm{P}$ value the higher the significance of the corresponding coefficient (Karthikeyan et al., 
1996). It can be seen in step-one that the variable with the most effect was the quadratic effect of initial $\mathrm{pH}$ of the medium $\left(\mathrm{X}_{2}{ }^{2}, \mathrm{~T}=7.82, \mathrm{P}=0.000\right)$ followed by linear effect of $\mathrm{pH}\left(\mathrm{X}_{2}, \mathrm{~T}=3.84, \mathrm{P}=\right.$ 0.004 ) and than quadratic effect of temperature $\left(\mathrm{X}_{1}^{2}, \mathrm{~T}=3.49, \mathrm{P}=0.007\right)$. The highest probability value of coefficient is the linear effect of rice bran supplementation (0.838), indicating that only $16 \%$ of the model is affected by this variable. Since linear and quadratic effect of initial $\mathrm{pH}$ of the medium is the most significant, meaning that it can act as limiting factor and little variation will alter the product formation rate. In the bioreactor, it shows that both linear effects and quadratic effects of agitation and aeration are highly significant (> $99 \%$ ).

The values of determination coefficient $\mathrm{R}^{2}$ (stepone) $=90.8 \%, \mathrm{R}^{2}$ (step-two) $=98.1 \%$ and the adjusted determination coefficient $\mathrm{R}^{2}$ (step-one) $=$ $87.6 \%$, adjusted determination coefficient $\mathrm{R}^{2}$ (step-two) $=97.2 \%$ of the significant factors are very high, indicating a high significance of the model (Akhnazarova and Kefarov, 1982; Khuri and Cornell, 1987) which is more suited for comparing models with different numbers of independent variables (Beg et al., 2003). This reveals a good agreement between the experimental and predicted values of phytatedegrading enzyme production.

The contour plots are graphical representations of the regression equation. The main goal of response surface is to hunt efficiently for the optimum values of the variables such that the response is maximized. Each contour curve represents an infinitive number of combination of two test variables with the other one maintained at their respective zero level. The maximum predicted value is indicated by the surface confined in the smallest ellipse in the contour diagram is the optimal region. Elliptical contours are obtained when there is a perfect interaction between the independent variables (Muralidhar et al., 2001).

From several studies (Park, and Reardon, 1996; Berka et al., 1998) the optimum temperature for the production of phytate-degrading enzymes of most of the micro-organisms lies in the range 25 to $37^{\circ} \mathrm{C}$. Using the regression equation, the predicted most optimum level of cultivation conditions for higher phytate-degrading enzyme production was found to be at an incubation temperature of 39.7 ${ }^{\circ} \mathrm{C}, \mathrm{pH} 7.1$ and $13.6 \%$ of rice bran concentration with $11.511 \mathrm{U} / \mathrm{ml}$ of enzyme yield. And when it was scale up in bioreactor for the optimization of agitation speed and aeration, the predicted optimum level of both factors were at $320 \mathrm{rpm}$ and at $0 \mathrm{vvm}$ it was $9.516 \mathrm{U} / \mathrm{ml}$. A study done by Segueilha et al. (1992), phytate-degrading enzyme production by Schwannimyces castellii was carried out continuously in a fermentor aerated at $1 \mathrm{vvm}$ and agitation kept at $600 \mathrm{rpm}$. Phytate-degrading enzyme was produced maximally by Bacillus sp. DS11 by shaking at $230 \mathrm{rpm}$ (Kim et al., 1998). And, phytate-degrading enzyme produced by Aspergillus niger, Aspergillus ficuum NRRL 3135 and Aspergillus terreus was carried out by shaking at $270 \mathrm{rpm}$ (Shieh and Ware, 1968). This indicates that optimum aeration and agitation are important to keep the cultivation conditions in a capable state.

The response surface model is a valuable tool for predicting and optimizing the cultivation conditions to maximize the phytate-degrading enzyme production. The results show that phytatedegrading enzyme production by Enterobacter sakazakii ASUIA279 can be improved by controlling various factors simultaneously. The validation model for both sets of experiments was in close agreement with the predicted value from the response surface model for phytate-degrading enzyme productions under the optimized cultivation conditions. The production of phytatedegrading enzyme was increased about 6-fold (compared to during screening) when cultivated at optimized condition in Erlenmeyer flask. However, the phytate-degrading enzyme production was decreased to 5-fold when the volume was scale-up in bioreactor. This could be due to the different environments in term of temperature, and volume between the two apparatus.

\section{ACKNOWLEDGEMENT}

This work has been supported by the Research Center, International Islamic University, Malaysia. Anis Shobirin MH is a fellow, National Science Fellowship, Ministry of Science, Technology and Innovation, Malaysia.

\section{REFERENCES}

Akhnazarova, S. and Kefarov, V. (1982), Experiment optimization in chemistry and chemical engineering. Moscow: Mir Publisher.

Anis Shobirin, M. H. (2008), Development of bioprocessing technique for the production and purification of phytate-degrading enzyme from 
Malaysian soil bacteria. PhD Thesis Dissertation. IIUM.

Beg, Q. K.; Saxena, R. K.; Gupta, R. (2002), Kinetic constants determination for an alkaline protease from Bacillus mojavensis using response surface methodology. Biotechnology Bioengineering, 78, 289-295.

Beg, Q. K.; Sahai, V.; Gupta, R. (2003), Statistical optimization and alkaline protease production from Bacillus mojavensis in a bioreactor. Proceeding Biochemistry, 39, 203-209.

Berka, R. M.; Rey, M. W.; Brown, K. M.; Byun, T.; Klotz, A. V. (1998), Molecular characterization and expression of a phytase gene from the thermophilic fungus Thermomyces lanuginosus. Applied Environmental Microbiology, 64, 44234427.

Bogar, B.; Szakacs, G.; Linden, J. C.; Pandey, A.; Tengerdy, R. B. (2003), Optimization of phytase production by solid substrate fermentation. Journal of Industrial Microbiology and Biotechnology, 30, 183-189.

Choi, Y. M.; Dong, O. N.; Cho, S. H.; Lee, H. K.; Suh, H. J.; Chung, S. H. (1999), Isolation of a phytase producing Bacillus sp. KHU-10 and its phytase production. Microbiology Biotechnology, 9, 223-226.

De Cornink, J.; Bouquelet, S.; Dumortier, V.; Duyme, F.; Denantes, V. I. (2000), Industrial media and fermentation process for improved growth and protease production by Tehrahymena thermophila BIII. Indian Microbiology Biotechnology, 24, 285-290.

Gautam, P.; Sabu, A.; Pandey, A.; Szakacs, G.; Soccol, C. (2002), Microbial production of extracellular phytase using polysterene as inert solid support. Bioresource Technology, 83, 229-233.

Greiner, R.; Konitzny, U.; Jany, K. D. (1993), Purification and characterization of two phytases from Escherichia coli. Achieves Biochemistry Biophysical, 303, 107-113.

Greiner, R.; Haller, E.; Konietzky, U.; Jany, K. D. (1997), Purification and characterization of a phytase from Klebsiella terrigena. Achieves Biochemistry Biophysical, 341, 201-206.
Heinonen, J. K. and Lahti, R. J. (1981), A new and convenient colorimetric determination of inorganic orthophosphate and its application to the assay of inorganic pyrophosphatase. Analysis Biochemistry, 113, 313-317.

Irving, G. C. J. and Cosgrove, D. J. (1971), Inositol phosphate phosphatases of microbiological origin. Some properties of partially purified bacterial (Pseudomonas sp.) phytase. Australian Journal Biological Science, 24, 547-557.

Irving, G. C. J. and Cosgrove, D. J. (1972), Inositol phosphate phophatase of microbiological origin: the inositol pentaphosphate products of Aspergillus ficuum phytase. Journal Bacteriology, 112, 434-438.

Karthikeyan, R. S.; Rakshit, S. K.; Baradarajan, A. (1996), Optimization of batch fermentation conditions for dextran production. Bioprocess Engineering, 15, 247-251.

Khuri, A. I. and Cornell, J. A. (1987), Response surfaces: design and analysis. New York: John Wiley and Sons, 291-334.

Kim, Y. O.; Kim, H. K.; Bae, K. S.; Yu, J. H.; Oh, T. K. (1998), Cloning of thermostable phytase gene (phy) from Bacillus sp. DS11 and its overexpression in Escherichia coli. FEMS Microbiology Letters, 162, 185-191.

Krishna, C. and Nokes, S. E. (2001), Predicting vegetative inoculum performance to maximize phytase production in solid-state fermentation using response surface methodology. Indian Microbiology Biotechnology, 26,161-170.

Mitchell, D. B.; Vogel, K.; Weimann, B. J.; Pasamontes, L.; Van Loon, A. S. P. G. M. (1997), The phytase subfamily of histidine acid phosphatases: isolation of gene for two novel phytases from the fungi Aspergillus tereus and Myceliophthora thermophila. Microbiology, 143, 245-252.

Muralidhar, R. V.; Chirumamila, R. R.; Marchant, R.; Nigam, P. (2001), A response surface approach for the comparison of lipase production by Candida cylindracea using two different carbon sources. Biochemistry Engineering, 9, 17-23. 
Nagashima, T.; Tange, T.; Anazawa, H. (1999), Dephosphorylation of phytase by using the Aspergillus niger phytase with a high affinity for phytate. Applied Environmental Microbiology, 65, 4682-4684.

Park, K. M. and Reardon, K. F. (1996), Medium optimization for recombinant protein production by Bacillus subtilis. Biotechnology Letters, 18, 737-740.

Pasamontes, L.; Haiker, M.; Wyss, M.; Tessier, M..; Van Loon A. P. G. M., (1997), Gene cloning, purification, and characterization of a heat-stable phytase from the fungus Aspergillus fumigatus. Applied Environmental Microbiology, 63, 16961700.

Poulsen, H. D. (2000), Phosphorus utilization and excretion in pig production. Journal Environmental Quality, 29, 24-27.

Powar, V. K. and Joganathan, V. (1982), Purification and properties of phytate specific phosphatase from Bacillus subtilis. Journal Bacteriology, 151, 1102-1108.

Puri, S.; Beg, Q. K.; Gupta, R. (2002), Optimization of alkaline protease production from Bacillus sp. using response surface methodology. Current Microbiology, 44, 286-290.
Quan, C.; Zhang, L.; Wang, Y.; Ohta Y. (2001), Production of phytase in a low phosphate medium by a novel yeast Candida krusei. Journal Bioscience Bioengineering, 92 154-160.

Segueilha, L.; Lambrechts, C.; Boze, H.; Moulin, G.; Galzy, P. (1992), Purification and properties of the phytase from Schwanniomyces castellii. Fermentation Bioengineering, 74, 7-11.

Shieh, T. R. and War,e J. H. (1968), Survey of microorganisms for the production of extracellular phytase. Applied Microbiology, 16, 1348-1351.

Vohra, A. and Satyanarayana, T. (2003), Phytases: Microbial sources, production, purification, and potential biotechnological applications. Critical Review Biotechnology, 23, 29-60.

Wodzinski, R. J. and Ullah, A. M. J. (1996), Phytase. Advance Applied Microbiology, 42, 263302.

Yamada, K.; Minoda, Y.; Yamamoto, S. (1968), Phytase from Aspergillus terreus 1. Production, purification and some general properties of the enzyme. Agriculture Biology Chemistry, 32, 12751282.

Yanke, L. J.; Bae, H. D., Selinger, L. B.; Cheng, K. J. (1998), Phytase activity of anaerobic ruminal bacteria. Microbiology, 144, 1565-1573. 